\title{
PENGARUH STRATEGI PEMBELAJARAN DAN KEBIASAAN BELAJAR TERHADAP HASIL BELAJAR IPA TERPADU
}

\author{
Ruth Maduma Silitonga dan Sahat Siagian ${ }^{2}$ \\ SMP Swasta T.D. Pardede Foundation ${ }^{1}$ dan Universitas Negeri Medan ${ }^{2}$ \\ rythmadumas@yahoo.com ${ }^{1}$ dan Sahat.sgn61@gmail.com ${ }^{2}$
}

\begin{abstract}
Abstrak: Penelitian ini bertujuan untuk mengetahui pengaruh strategi pembelajaran dan kebiasaan belajar terhadap hasil belajar IPA terpadu. Metode yang digunakan adalah metode quasi-eksperimental method yang dilaksanakan di SMP Swasta T.D. Pardede Foundation Kab. Deli Serdang, dengan populasi seluruh siswa kelas VII, pada semester I (satu), dengan sampel adalah siswa pada kelas VII-A, dan siswa pada kelas VII-D yang diambil secara cluster random sampling. Hasil penelitian menunjukkan bahwa siswa yang diajar dengan strategi pembelajaran investigasi kelompok memiliki hasil belajar yang lebih tinggi jika dibandingkan dengan siswa yang diajar dengan strategi pembelajaran ekspositori, $F h=179.13>F t=4,02$ pada $\alpha=0.05$. Siswa dengan kebiasaan belajar yang baik memiliki hasil belajar yang lebih tinggi dibandingkan dengan siswa yang memiliki kebiasaan belajar yang kurang baik $(F h=4.68>F t=4.02)$, ada interaksi antara strategi pembelajaran dan kebiasaan belajar siswa terhadap hasil belajar biologi $(F h=$ $11.05>$ Ft (4.02), $\alpha=0.05$ ). Uji lanjut dengan Uji scheffe menunjukkan bahwa siswa yang diajar dengan strategi pembelajaran investigasi kelompok dengan kebiasaan belajar yang baik hasil belajarnya lebih tinggi jika dibandingkan dengan siswa yang diajar dengan strategi pembelajaran ekspositori dengan kebiasaan belajar yang kurang baik.
\end{abstract}

Kata Kunci: strategi pembelajaran, kebiasaan belajar, ilmu pengetahuan alam terpadu

Abstract: This study aims to determine the effect of learning strategies and study habits to learning the results of the integrated IPA. The method used is the method of quasi-experimental method are carried out in private junior TD Pardede Foundation Kab. Deli Serdang, with the entire population of students of class VII, in the first semester (one), the samples are students in the class VII-A, and the students in the class VII-D drawn at random cluster sampling. The results showed that students taught by instructional strategies investigative group had a higher learning outcomes when compared with students who are taught by expository strategy, $F c=179.13>F t=4.02$ at $\alpha=$ 0:05. Students with good study habits have learning outcomes are higher compared with students who have learning habits that are less well $(F c=4.68>F t=4.02)$, there is an interaction between learning strategies and study habits of students' learning outcomes biology $(F c=11: 05$ a.m. $>\mathrm{ft}$ (4:02), $\alpha=0.05$ ). Further test with Scheffe test showed that students taught by instructional strategies investigative group with good study habits study results higher when compared with students who are taught by expository teaching strategy with less good study habits.

Keywords: learning strategies, study habits, an integrated natural sciences

\section{PENDAHULUAN}

Ilmu Pengetahuan Alam (IPA) terpadu adalah salah satu mata pelajaran siswa tingkat Sekolah Menengah Pertama (SMP). Secara umum, pelajaran IPA terpadu mempelajari tentang gejala alam untuk memahami alam apa adanya. Dengan mempelajari rahasia alam, orang mencoba menerapkannya untuk kesejahteraan umat manusia. Dikatakan IPA terpadu karena terdiri dari pelajaran Biologi, Fisika dan Kimia. Pelajaran yang membahas tentang alam mencakup pengetahuan tentang zat dan sifat-sifatnya yang dibahas dalam Kimia, makhluk hidup dan sifat-sifatnya yang dibahas dalam Biologi, dan fenomena alam yang dibahas dalam Fisika. IPA terpadu merupakan ilmu dasar dari eksakta dan cabang ilmu lainnya, seperti teknik, perindustrian dan bioteknologi. Hal ini menjadi alasan mengapa IPA terpadu menjadi salah satu pelajaran wajib di tingkat SMP dan bahkan menjadi salah satu pelajaran yang ikut diujikan dalam U.N (Ujian Nasional). 
Kemampuan mereka dalam memahami materi IPA terpadu secara keseluruhan dipengaruhi oleh kemampuan mereka dalam memahami pelajaran biologi, pelajaran kimia dan pelajaran fisika. Namun dalam penelitian ini, dibatasi pada pelajaran biologi saja oleh karena keterbatasan peneliti.

Biologi adalah salah satu bagian dari mata pelajaran IPA terpadu. Pelajaran biologi mengkaji tentang makhluk hidup dan segala aspek yang menyertainya. Pada pelajaran biologi, siswa diharapkan mampu menguasai materi pembelajaran secara teoritis dan mampu mengaplikasikan pengetahuannya dalam praktek baik di laboratorium/sekolah maupun dalam kehidupan sehari-hari. Adanya tuntutan kualifikasi kompetensi ini, maka siswa harus mampu mengaktualisasikan pengetahuannya secara cermat dan teliti. Mengingat biologi adalah ilmu dasar bagi bidang kedokteran, pertanian, analis, farmasi dan perindustrian, maka para siswa harus memiliki pemahaman dan penguasaan materi materi biologi dengan baik. Sehingga pada saatnya kelak, mereka memiliki pengetahuan dasar yang baik ketika mereka melanjutkan pendidikan yang lebih tinggi, atau juga berguna untuk diri sendiri. Diharapkan juga, para siswa dapat mengukir prestasi pada U.N (Ujian Nasional) dan OSN tingkat nasional.

Berdasarkan hasil observasi dan wawancara yang dilakukan kepada siswa adalah mereka mengatakan bahwa biologi merupakan pelajaran yang pada dasarnya menyenangkan, tetapi yang menjadi kendala adalah pelajaran biologi sering dianggap sebagai pelajaran hapalan saja, mereka sering memaksa diri untuk menghafal, meskipun mereka belum begitu memahaminya.

Kurangnya prestasi belajar biologi SMP

Swasta T.D. Pardede Foundation ini dipengaruhi oleh banyak faktor. Salah satu faktor yang mungkin sangat mempengaruhi hasil belajar ini adalah strategi pembelajaran biologi yang selama ini digunakan oleh guru dalam penyampaian materi pelajaran biologi. Selama ini, strategi pembelajaran yang digunakan adalah strategi pembelajaran ekspositori dengan metode ceramah dan penyelesaian soal-soal latihan di sekolah. Strategi pembelajaran tersebut menyebabkan siswa belajar biologi dengan pendekatan fakta dan konsep. Menurut Syamsuri (2007), belajar dengan pendekatan konsep dan fakta dapat melelahkan dalam belajar dan menimbulkan sikap pasif pada diri siswa.
Dalam pelajaran biologi, ada yang dapat dipelajari dengan melakukan pengamatan ataupun praktik, siswa tersebut bisa melibatkan dirinya untuk mencari ilmu tersebut, sehingga siswa tersebut tidak hanya menghafalkan konsep dan fakta saja. Oleh karena itu, untuk memecahkan masalah prestasi belajar siswa tersebut, perlu diterapkan strategi pembelajaran yang tepat agar siswa dapat menguasai materi pelajaran biologi dan menerapkannya dalam kehidupan sehari-hari.

Belajar adalah modifikasi atau memperteguh kelakuan melalui pengalaman (learning is defined as the modification or strengthening of behavior through experiencing). Menurut pengertian ini, belajar merupakan suatu proses, suatu kegiatan dan bukan suatu hasil atau tujuan. Belajar bukan hanya mengingat, akan tetapi lebih luas dari itu, yakni mengalami. Hasil belajar bukan hasil penguasaan suatu latihan, melainkan pengubahan kelakuan (Hamalik, 2001).

Belajar merupakan peristiwa sehari-hari di sekolah. Belajar merupakan hal yang kompleks. Kompleksitas belajar tersebut dapat dipandang dari dua subjek, yaitu dari siswa dan dari guru. Dari segi siswa, belajar dialami sebagai suatu proses. Siswa mengalami proses mental dalam menghadapi bahan belajar. Bahan belajar tersebut berupa keadaan alam, hewan, tumbuh-tumbuhan, manusia dan bahan yang telah terhimpun dalam buku-buku pelajaran. Dari segi guru, proses belajar tersebut tampak sebagai perilaku belajar tentang sesuatu hal (Nasution, 1987).

Belajar merupakan proses internal yang kompleks. Yang terlibat dalam proses internal tersebut adalah seluruh mental yang meliputi ranah-ranah kognitif, afektif dan psikomotorik. Proses belajar yang mengaktualisasikan ranahranah tersebut tertuju pada bahan belajar tertentu. Dengan belajar, maka kemampuan siswa meningkat. Ranah-ranah kognitif, afektif dan psikomotorik siswa semakin berfungsi. Sebagai ilustrasi, pada ranah kgnitif siswa dapat memiliki pengetahuan, pemahaman dapat menerapkan, melakukan analisis, sintesis, dan mengevaluasi. Pada ranah afektif siswa dapat melakukan penerimaan, partisipasi, menentukan sikap, mengorganisasi dan membentuk pola hidup. Pada ranah psikomotorik, siswa dapat mempersepsi, bersiap diri, membuat gerakangerakan sederhana dan kompleks, membuat penyesuaian pola gerak, dan menciptakan gerak-gerak baru (Mudjiono \& Dimyati, 2006). 


\begin{abstract}
Biologi adalah salah satu mata pelajaran ilmu pengetahuan alam yang dipelajari oleh siswa. Biologi merupakan ilmu yang mempelajari tentang makhluk hidup dan segala aspek yang menyertainya. Biologi merupakan ilmu dasar (basic science) dari ilmu-ilmu yang lain, seperti ilmu bidang kedokteran, pertanian, farmasi, industry pangan dan lain-lain (Syamsuri, 2007). Mengingat peranan biologi yang sangat penting dalam kehidupan manusia, maka biologi menjadi salah satu mata pelajaran wajib, baik untuk tingkat SMP (Sekolah Menengah Pertama) maupun SMA (Sekolah Menengah Atas) yang merupakan bagian dari pelajaran IPA terpadu. Biologi juga ikut diujikan dalam ujian nasional dan olimpiade sains dari tingkat kabupaten hingga tingkat internasional.
\end{abstract}

Menurut Syamsuri, (2007), mempelajari biologi dapat dilakukan dengan tiga pendekatan, antara lain: (1) Pendekatan fakta. Belajar dengan pendekatan fakta adalah belajar dengan menghafalkan fakta-fakta. Belajar dengan fakta berarti menganggap bahwa ilmu hanya sebagai gudang fakta. Akibatnya, siswa akan pasif dan hanya senang mendengarkan ceramah guru yang bercerita. Siswa akan menjadi seperti gelas kosong yang harus dituangi ilmu; (2) Pendekatan konsep. Konsep adalah hubungan dua fakta atau lebih yang membentuk satu pengertian. Belajar dengan pendekatan konsep lebih baik daripada pendekatan fakta. Hanya saja, siswa masih pasif dan belum berupaya sendiri; (3) Pendekatan keterampilan proses. Belajar dengan pendekatan keterampilan proses adalah belajar sebagaimana cara seorang ilmuwan mendapatkan ilmu. Siswa mendapatkan sendiri fakta dan konsep. Hasil belajar yang demikian dapat bertahan dalam waktu lama serta dapat membentuk sikap dan keterampilan ilmiah. Hasil belajar dapat diterapkan untuk memecahkan persoalanpersoalan lain yang dihadapi siswa. Siswa dapat menjadi aktif dan kreatif. Siswa akan dapat "menemukan" ilmu itu sendiri.

Dengan demikian, pada kegiatan pembelajaran pendekatan keterampilan proses ini, ilmu pengetahuan, unsur keterampilan proses serta sikap dan nilai saling berinteraksi dan berpengaruh satu sama lain, dan teori belajar yang mendukung hal ini adalah teori belajar Ausubel tentang belajar bermakna dan teori belajar konstruktivisme (Mudjiono \& Dimyati, 2006).

Dalam dunia pendidikan, strategi diartikan sebagai a plan, method, or series of activities designed to achieves a particular educational goal (J.R. David, 1976 dalam Sanjaya, 2009, p.126). Jadi dengan demikian, strategi pembelajaran dapat diartikan sebagai perencanaan yang berisi tentang rangkaian kegiatan yang didesain untuk mencapai tujuan pendidikan tertentu.

Kemp (1995) dalam Sanjaya, 2009 menyatakan bahwa strategi pembelajaran adalah suatu kegiatan pembelajaran yang harus dikerjakan guru dan siswa agar tujuan pembelajaran dapat dicapai secara efektif dan efisien. Senada dengan hal itu, Dick and Carey (1985) dalam Sanjaya (2009) juga menyatakan bahwa strategi pembelajaran itu adalah suatu set materi dan prosedur pembelajaran yang digunakan secara bersama-sama untuk menimbulkan hasil belajar pada siswa.

Pembelajaran kooperatif bernaung dalam teori konstruktivisme. Pembelajaran ini muncul dari konsep bahwa siswa akan lebih mudah menemukan dan memahami konsep yang sulit jika mereka saling berdiskusi dengan temannya. Siswa secara rutin bekerja dalam kelompok untuk saling membantu memecahkan masalah-masalah yang kompleks. Jadi, hakikat sosial dan penggunaan kelompok sejawat menjadi aspek utama dalam pembelajaran kooperatif (Trianto, 2009).

Konstruktivisme merupakan salah satu aliran filsafat pengetahuan yang menekankan bahwa pengetahuan kita merupakan hasil kontruksi (bentukan) kita sendiri. Pengetahuan bukanlah suatu imitasi dari kenyataan dan bukanlah gambaran dari dunia kenyataan yang ada. Pengetahuan selalu merupakan akibat dari suatu konstruksi kognitif dari kenyataan yang terjadi melalui serangkaian aktivitas seseorang. Seseorang (pebelajar) membentuk skema, kategori, konsep dan struktur pengetahuan yang diperlukan untuk pengetahuan. Pengetahuan bukanlah tentang hal-hal yang terlepas dari pengamat, tetapi merupakan ciptaan manusia yang dikonstruksikannya dari pengalaman atau dunia yang dialaminya. Proses pembentukan ini berjalan terus-menerus dan setiap kali terjadi reorganisasi atau rekonstruksi karena adanya suatu pemahaman yang baru (Hamid, 2009; Suparno, 1997).

Dalam Hamid (2009) dan Suparno (1997) dinyatakan: menurut konstruktivisme, belajar merupakan proses aktif pebelajar mengkonstruksi arti, wacana, dialog, pengalaman fisik dan lain-lain. Belajar juga merupakan proses mengasimilasi dan menghubungkan pengalaman atau informasi 
yang dipelajari dengan pengertian yang sudah dimiliki pebelajar sehingga pengetahuannya berkembang.

Menurut Driver dan Oldham dalam Matthews (1994) yang dinyatakan kembali dalam Hamid (2009), pembelajaran berlandaskan konstruktivisme akan bercirikan sebagai berikut: (1) Orientasi. Pebelajar diberi kesempatan untuk mengembangkan motivasi dalam mempelajari suatu topik. Pebelajar diberi kesempatan untuk mengadakan observasi terhadap topik yang hendak dipelajari; (2) Elisitasi. Pebelajar dibantu untuk mengungkapkan idenya secara jelas dengan berdiskusi, menulis, membuat poster, dan lainlain. Pebelajar diberi kesempatan untuk mendiskusikan apa yang diobservasikan dalam wujud tulisan, gambar ataupun poster; (3) Restrukturisasi ide. Restrukturisasi ide merupakan: klarifikasi ide yang dikontraskan dengan ide-ide orang lain atau teman lewat diskusi ataupun pengumpulan ide. Berhadapan dengan ide-ide lain, seseorang dapat terangsang untuk mengkonstruksi gagasannya kalau tidak cocok atau sebaliknya, menjadi lebih yakin bila gagasannya cocok; Membangun ide yang baru yang dapat terjadi bila dalam diskusi itu idenya bertentangan dengan ide lain atau idenya tidak dapat menjawab pertanyaan-pertanyaan yang diajukan teman-temannya; Mengevaluasi ide barunya dengan eksperimen; (4) Penggunaan ide dalam banyak situasi. Ide atau pengetahuan yang telah dibentuk oleh pebelajar perlu diaplikasikan pada bermacam-macam situasi yang dihadapi, sehingga menjadi lebih lengkap dan bahkan lebih rinci dengan segala macam kondisinya; (5) Review, bagaimana ide berubah. Dapat terjadi bahwa dalam mengaplikasikan pengetahuannya, seseorang perlu merevisi gagasannya, apa dengan menambahkan suatu keterangan ataupun mungkin dengan mengubahnya menjadi lebih lengkap.

Jelas bahwa bagi konstruktivisme, kegiatan belajar adalah kegiatan yang aktif, dimana pelajar membangun sendiri pengetahuannya. Pelajar mencari arti sendiri dari yang mereka pelajari. Ini merupakan proses menyesuaikan konsep dan ide-ide baru dengan kerangka berpikir yang telah ada dalam pikiran mereka. Menurut konstruktivisme, pelajar sendirilah yang bertanggungjawab atas hasil belajarnya. Mereka membawa pengertiannya yang lama dalam situasi belajar yang baru. Mereka sendiri yang membuat penalaran atas apa yang dipelajarinya dengan cara mencari makna, membandingkannya dengan apa yang telah ia ketahui serta menyelesaikan ketegangan antara apa yang telah ia ketahui dengan apa yang ia perlukan dalam pengalaman yang baru (Suparno, 1997).

Karena pengetahuan dibentuk baik secara individual maupun sosial, maka kelompok belajar dapat dikembangkan (Shymansky, 1992; Watts \& Pope, 1989 dalam Suparno, 1997). Von Glasersfeld (1989) menjelaskan bagaimana pengaruh konstruktivisme terhadap belajar dalam kelompok. Menurut dia, dalam kelompok belajar siswa harus mengungkapkan bagaimana ia melihat persoalan dan apa yang akan dibuatnya dengan persoalan itu. Inilah salah satu jalan menciptakan refleksi yang menuntut kesadaran akan apa yang sedang dipikirkan dan dilakukan. Selanjutnya ini akan memberikan kesempatan kepada seseorang untuk secara aktif membuat abstraksi. Usaha menjelaskan sesuatu kepada kawan-kawan justru membantunya untuk melihat sesuatu dengan lebih jelas dan bahkan melihat inkonsistensi pandangan mereka sendiri (Suparno, 1997).

Para pendidik melihat komunikasi kelompok sebagai metode pendidikan yang efektif (Rakhmat, 2002). Barnard (1938) dalam Rakhmat (2002), menyatakan bahwa faktor yang mempengaruhi keefektifan kelompok adalah "The accomplishment of the recognized objectives of cooperative action". Anggotaanggota kelompok bekerjasama untuk mencapai dua tujuan: melaksanakan tugas kelompok dan memelihara moral anggota-anggotanya. Tugas kelompok ialah memecahkan masalah atau melahirkan gagasan-gagasan baru. Peranan tugas berhubungan dengan upaya memudahkan dan mengkoordinasi kegiatan yang menunjukkan tercapainya tujuan kelompok. Tujuan pertama diukur dari hasil kerja kelompok disebut prestasi (performance). Tujuan kedua diukur dari tingkat kepuasan (satisfaction). Jadi bila kelompok dimaksudkan untuk saling berbagi informasi (misalnya kelompok belajar), maka keefektifannya dapat dilihat dari berapa banyak informasi yang diperoleh anggota kelompok dan sejauh mana anggota dapat memuaskan kebutuhannya dalam kegiatan kelompok. Faktor keefektifan kelompok dapat dilacak pada karakteristik kelompok (faktor situasional) dan pada karakteristik para anggotanya (faktor personal). Johnson \& Johnson (1994) dalam Trianto (2009) menyatakan bahwa tujuan pokok belajar kooperatif adalah memaksimalkan belajar siswa untuk peningkatan prestasi 
akademik dan pemahaman, baik secara individu maupun secara kelompok. Karena siswa bekerja dalam suatu team, maka dengan sendirinya dapat memperbaiki hubungan diantara para siswa dari berbagai latar belakang etnis dan kemampuan, mengembangkan keterampilanketerampilan proses kelompok dalam pemecahan masalah ( Louisell \& Descamps,1992 dalam Trianto, 2009).

Menurut Johnson \& Johnson (1994) dan Sutton (1992) dalam Trianto (2009), unsurunsur penting dan prinsip utama pembelajaran kooperatif adalah: Saling ketergantungan yang bersifat positif antara siswa ketika mereka sedang bekerjasama untuk mencapai satu tujuan dan terikat satu sama lain, merasa bahwa dirinya adalah bagian dari kelompok yang juga mempunyai andil terhadap suksesnya kelompok; Interaksi antara siswa juga meningkat saat mereka saling memberikan bantuan dalam hal tukar menukar ide mengenai masalah yang sedang dipelajari bersama; Tanggung jawab individual dalam belajar kelompok dapat berupa tanggung jawab siswa dalam hal: (a) membantu siswa yang membutuhkan bantuan dan (b) siswa tidak dapat hanya sekedar "membonceng" pada hasil kerja teman jawab siswa dan teman sekelompoknya; Keterampilan interpersonal dan kelompok kecil. Dalam belajar kooperatif, selain dituntut untuk mempelajari materi yang diberikan, seorang siswa dituntut untuk belajar bagaimana berinteraksi dengan siswa lain dalam kelompoknya. Bagaimana sikap siswa sebagai anggota kelompok dan menyampaikan ide dalam kelompok akan menuntut keterampilan khusus; Proses kelompok. Proses kelompok terjadi jika anggota kelompok mendiskusikan bagaimana mereka akan mencapai tujuan dengan baik dan membuat hubungan kerja yang baik.

Walaupun prinsip dasar pembelajaran kooperatif tidak berubah, terdapat beberapa variasi dari strategi pembelajaran tersebut, yaitu: STAD (Student Teams Acievement Division), Jigsaw, Investigasi kelompok, TGT (Teams Games Tournaments) dan pendekatan structural yang meliputi TPS (Think Pair Share) dan NHT (Numbered Head Together).

Investigasi kelompok merupakan strategi pembelajaran kooperatif yang. pertama kali dikembangkan oleh Thelan. Dalam perkembangannya, strategi ini diperluas dan dipertajam oleh Sharan dari universitas Tel Aviv. Berbeda dengan STAD dan Jigsaw, siswa terlibat dalam perencanaan baik topik yang dipelajari dan jalannya penyelidikan mereka. Pendekatan ini memerlukan norma mengajar siswa keterampilan komunikasi dan proses kelompok yang baik (Trianto, 2009).

Secara umum, guru menetapkan sebuah topik utama pelajaran, kemudian memecahnya menjadi beberapa sub topik. Setiap sub topik yang menjadi minat setiap kelompok akan dipecahkan oleh masing-masing kelompok siswa tersebut. Sebagai bagian dari proses penyelidikan, para siswa akan mencari informasi dari berbagai sumber baik di dalam, maupun di luar sekolah. Berbagai sumber tersebut (seperti buku, institusi, orang-orang) akan memunculkan ide, opini, data dan berbagai solusi atau posisi, tergantung pada masalah apa yang sedang diselidiki. Siswa kemudian akan melakukan evaluasi dan sintesis berdasarkan informasi yang telah disampaikan oleh setiap anggota kelompok (Slavin, 1995).

Sharan, dkk (1984) dalam Trianto (2009) serta Slavin (1995) membagi langkahlangkah pelaksanaan strategi investigasi kelompok menjadi enam fase, yaitu: (1) Memilih topik. Siswa memilih suptopik khusus di dalam suatu daerah masalah umum yang biasanya ditetapkan oleh guru. Selanjutnya, siswa diorganisasikan menjadi dua sampai enam anggota tiap kelompok menjadi kelompok-kelompok yang berorientasi tugas. Komposisi kelompok hendaknya heterogen secara akademis maupun etnis; (2) Perencanaan kooperatif. Siswa dan guru merencanakan prosedur pembelajaran, tugas dan tujuan khusus yang konsisten dengan subtopik yang telah dipilih pada tahap pertama; (3) Implementasi. Siswa menerapkan rencana yang telah mereka kembangkan di dalam tahap kedua. Kegiatan pembelajaran hendaknya melibatkan ragam aktivitas dan keterampilan yang luas dan hendaknya mengarahkan siswa kepada jenisjenis sumber belajar yang berbeda baik di dalam atau di luar sekolah. Guru secara ketat mengikuti kemajuan tiap kelompok dan menawarkan bantuan bila diperlukan; (4) Analisis dan sintesis, siswa menganalisis dan menyintesis informasi yang diperoleh pada tahap ketiga dan merencanakan bagaimana informasi tersebut diringkas dan disajikan dengan cara yang menarik sebagai bahan untuk dipresentasikan kepada seluruh kelas; (5) Presentasi hasil final. Beberapa atau semua kelompok menyajikan hasil penyelidikannya dengan cara yang menarik kepada seluruh kelas, dengan tujuan agar siswa yang lain saling terlibat satu sama lain dalam pekerjaan mereka 
dan memperoleh perspektif yang luas pada topik itu. Presentasi dikoordinasi oleh guru; (6) Evaluasi. Dalam hal kelompok-kelompok menangani aspek yang berbeda dari topik yang sama, siswa dan guru mengevaluasi tiap kontribusi kelompok terhadap kerja kelas sebagai suatu keseluruhan. Evaluasi yang dilakukan dapat berupa penilaian individual atau kelompok.

Ada dua konsep dasar yang penting di dalam investigasi kelompok, yaitu: penelitian dan pengetahuan (Joyce et.al. (2009), Joyce \& Weil, (1996). Penelitian. Penelitian di dorong adanya tantangan yang berupa sebuah masalah, yakni pengetahuan yang di dapat dari proses penelitian. Proses sosial meningkatkan penelitian serta pembelajaran dan pengembangan penelitian tersebut. Inti dari investigasi kelompok terletak pada rumusan penelitian. Menurut Thelen, hal yang menyangkut penelitian adalah: memprakarsai dan mengawasi proses-proses dalam memperhatikan sesuatu; proses-proses berinteraksi dengan dan terdorong oleh orang lain, baik melalui orangnya, maupun melalui tulisan mereka; dan proses-proses refleksi dan pengolahan kembali konsep dan sikap-sikap seperti yang ditunjukkan dengan keberhasilan mencapai kesimpulan-kesimpulan, mengidentifikasi investigasi-investigasi baru yang akan diterapkan, bertindak dan menciptakan hasil yang lebih baik (Joyce et. al., 2009).

Strategi pembelajaran ekspositori adalah strategi pembelajaran yang menekankan kepada proses penyampaian materi secara verbal dari seorang guru kepada sekelompok siswa dengan maksud agar siswa dapat menguasai materi pelajaran secara optimal. Roy Killen (1998) dalam Sanjaya (2009) menamakan strategi ekspositori ini dengan istilah strategi pembelajaran langsung (direct instruction), karena dalam strategi ini materi pelajaran disampaikan langsung oleh guru. Siswa tidak dituntut untuk menemukan materi itu. Materi pelajaran seakan-akan sudah jadi. Oleh karena strategi ekspositori lebih menekankan kepada proses bertutur, maka sering juga dinamakan istilah strategi "chalk and talk" (Sanjaya, 2009).

Beberapa karakteristik strategi ekspositori antara lain: pertama, Strategi ekspositori dilakukan dengan cara menyampaikan materi pelajaran secara verbal, artinya bertutur secara lisan merupakan alat utama dalam melakukan strategi ini, oleh karena itu, orang sering mengidentikkannya dengan ceramah. Kedua, biasanya materi pelajaran yang disampaikan adalah materi pelajaran yang sudah jadi, seperti data atau fakta, konsep-konsep tertentu yang harus dihafal sehingga tidak menuntut siswa untuk memahaminya dengan benar dengan cara dapat mengungkapkan kembali materi yang telah diuraikan (Sanjaya, 2009).

Strategi pembelajaran ekspositori merupakan bentuk dari pendekatan pembelajaran yang berorientasi kepada guru (teacher centered approach). Dikatakan demikian, sebab dalam strategi ini guru memegang peranan yang sangat dominan. Melalui strategi ini, guru menyampaikan materi pembelajaran secara terstruktur, dengan harapan materi pelajaran yang disampaikan itu dapat dikuasai siswa dengan baik. Fokus utama strategi ini adalah kemampuan akademik (academic achievement) siswa. Strategi pembelajaran dengan kuliah merupakan bentuk strategi ekspositori (Sanjaya, 2009; Djamarah \& Zain, 2006), merupakan suatu cara mengajar yang digunakan untuk menyampaikan keterangan atau informasi tentang suatu pokok persoalan serta masalah secara lisan (Djamarah \& Zain, 2006).

Metode ceramah merupakan metode tradisional, karena sejak dulu metode ini telah dipergunakan sebagai alat komunikasi lisan antara guru dengan anak didik dalam proses belajar mengajar. Meski metode ini lebih banyak menuntut keaktifan guru daripada anak didik, tetapi metode ini tetap tidak bisa ditinggalkan begitu saja dalam kegiatan pengajaran. Apalagi dalam pendidikan dan pengajaran tradisional, seperti dipedesaan yang kekurangan fasilitas ( Djamarah \& Zain, 2006).

Para ahli psikologi membagi tiga tahapan ingatan, yaitu: memasukkan pesan dalam ingatan (encoding), penyimpanan (storage), dan mengingat kembali (retrieval). Ingatan terbagi atas dua jenis, yaitu ingatan jangka pendek dan ingatan jangka panjang (Atkinson et.al., 1983). Sistem organ dalam tubuh manusia yang berfungsi untuk mengatur dan mengendalikan semua aktivitas tubuh adalah sistem saraf yang terdiri dari sistem saraf pusat dan sistem saraf tepi. Sistem saraf pusat terdiri dari otak dan sumsum tulang belakang. Aktivitas berpikir, mengingat ataupun kemampuan belajar dikendalikan oleh otak (Reece \& Mitchell,2004). Semua kecerdasan ada dalam otak sejak lahir. Menurut Dryde \& Jeannette Vos (2003) otak akan mampu bekerja 
secara efektif dengan menggunakannya secara teratur, sehingga proses belajarpun akan menjadi lebih mudah dan lebih sederhana.

Dunia yang cepat berubah menuntut dan mensyaratkan kemampuan belajar yang lebih cepat. Kompleksitas dunia yang terus meningkat juga menuntut kemampuan yang sesuai untuk menganalisis setiap situasi secara logis dan memecahkan masalah secara kreatif. Kemampuan untuk meraih sukses berbanding lurus dengan kemampuan belajar (Nicholl \& Rose, 2002).

Pekerjaan yang paling bernilai dimasa depan adalah "pekerjaan otak" atau pekerjaan yang memerlukan bakat besar dan terlatih baik di dunia musik, seni atau olahraga, misalnya. Pada masa yang berubah sangat cepat seperti sekarang ini, kita harus memiliki dua keterampilan super, yaitu belajar cepat dan berpikir jernih. Kedua keterampilan itu akan menghasilkan kemandirian dan kepercayaan diri. Kemandirian merupakan kemampuan untuk mengelola cara belajar sejak dini, untuk menguasai volume informasi yang cukup besar, melihat signifikansinya yang sebenarnya, dan untuk mengetahui bagaimana menggunakan informasi itu untuk melahirkan produk-produk dan jawaban-jawaban kreatif terhadap berbagai masalah. Kita harus belajar lebih baik, berpikir lebih tajam dan berdaya cipta lebih kreatif dibanding dengan para pesaing kita (Nicholl \& Rose, 2002).

Pada sekolah lanjutan tingkat pertama, siswa harus mampu belajar secara mandiri, sehingga mereka bisa memanfaatkan peluangpeluang yang memikat dari alat-alat bantu belajar interaktif yang baru. Kendatipun demikian, mereka juga harus bisa bekerja secara bersama untuk mengatasi berbagai masalah, seperti masalah-masalah masyarakat yang nyata, yang melibatkan kepentingan mereka karena masalah-masalah itu relevan dengan kehidupan mereka. Dengan cara demikian, para siswa mengembangkan keterampilan dasar mereka dan sekaligus belajar mengembangkan keterampilan berpikir kreatif dan kritis. Dengan kata lain, kita membutuhkan perubahan, baik dalam apa yang dipelajari dan dalam cara bagaimana ia dipelajari (Nicholl \& Rose

Dalam proses belajar, pembiasaan juga meliputi pengurangan perilaku yang tidak diperlukan. Karena proses penyusutan/pengurangan inilah, muncul suatu pola bertingkah laku baru yang relatif menetap dan otomatis. Kebiasaan ini terjadi karena prosedur pembiasaan seperti dalam classical dan operant conditioning. Contoh, siswa yang belajar bahasa berkali-kali menghindari kecenderungan penggunaan kata atau struktur yang keliru, akhirnya akan terbiasa dengan penggunaan bahasa secara baik dan benar. Jadi, berbahasa secara baik dan benar itulah perwujudan perilaku belajar siswa tadi (Syah, 2010).

Kegiatan belajar yang ada pada pendidikan lanjutan tingkat pertama menuntut siswa untuk belajar lebih aktif dan mandiri, hal ini karena materi pelajaran yang harus dipelajari sangat banyak, sementara waktu belajar dan mengajar di sekolah sangat terbatas. Kebiasaan yang dimiliki oleh siswa dalam belajar akan mempengaruhi tingkah lakunya dalam mencapai tujuan pembelajaran di sekolah. Jika seorang siswa dalam menerapkan cara belajar tertentu menyebabkan dia mendapat nilai yang baik, maka itu akan tetap diterapkannya, agar dia selalu mendapat nilai yang baik, sementara cara belajar yang tidak memberikan hasil belajar yang baik akan ditinggalkannya. Pengalaman dalam belajar tersebut akan menjadi suatu kebiasaan yang akan dimiliki oleh siswa (Nicholl \& Rose, 2002).

Kebiasaan dan sikap belajar yang baik adalah kebiasaan belajar secara efisien, teratur dan berencana (Hamalik,1993). Oleh karena itu, seorang siswa dalam belajar sebaiknya merencanakan waktu belajar dengan membuat dan melaksanakan secara teratur jadwal belajar, menentukan apa yang akan dipelajari, berapa lama dia akan belajar serta mencari literature dari berbagai sumber sesuai dengan topik yang dipelajarinya.

Menurut De Porter \& Hernacki (2002), siswa harus terampil dalam menerapkan caracara belajar agar belajar dapat menjadi menyenangkan. Oleh karena itu, untuk mengukur kebiasaan belajar, dilakukan dengan melihat kebiasaan belajar baik dan kebiasaan belajar yang tidak baik. Siswa yang memiliki kebiasaan belajar baik, dia akan melakukan kebiasaan tersebut terus menerus, sedangkan siswa yang memiliki kebiasaan belajar yang tidak baik, dia tidak melakukan kegiatan tersebut secara rutin.

Perumusan masalah-masalah yang akan diteliti dalam penelitian ini adalah sebagai berikut: (1) Apakah hasil belajar biologi siswa yang diajar dengan menggunakan strategi pembelajaran kooperatif tipe investigasi kelompok lebih tinggi dibandingkan dengan hasil belajar siswa yang diajar dengan menggunakan strategi pembelajaran 
ekspositori?; (2) Apakah hasil belajar biologi yang memiliki kebiasaan belajar baik lebih tinggi dibandingkan dengan siswa yang memiliki kebiasaan belajar yang tidak baik?; dan (3) Apakah ada interaksi antara strategi pembelajaran dengan kebiasaan belajar terhadap hasil belajar biologi?

\section{METODE}

Penelitian ini telah dilaksanakan di SMP Swasta T.D. Pardede Foundation. Populasi dalam penelitian ini adalah seluruh siswa kelas VII, SMP Swasta T.D. Pardede Foundation pada semester I (satu) yang terdiri dari 156 orang siswa dengan distribusi 38 orang pada kelas VII-A, 40 orang pada kelas VII-B, dan 40 orang pada kelas VII-C, dan 40 orang pada kelas VII-D. Penarikan sampel dilakukan secara acak melalui undian yakni dari 4 kelas diperoleh 2 kelas eksperimen. Teknik pengambilan sampel dilakukan dengan teknik cluster random sampling, dari 2 kelas yang telah terpilih sebagai sampel penelitian, selanjutnya melalui pengundian maka kelas VII-A terpilih sebagai kelas yang akan diberi perlakuan dengan strategi pembelajaran investigasi kelompok, sedangkan kelas VII-D terpilih sebagai kelas yang akan diberi perlakuan dengan strategi pembelajaran ekspositori. Penelitian ini menggunakan metode eksperimental semu (quasi-eksperimental method). Rancangan desain faktorial $2 \times 2$ ini, digunakan dengan maksud untuk memperkecil kesalahan dalam perbedaan hasil belajar biologi yang disebabkan oleh tingkat kebiasaan belajarnya. Dengan demikian, angket kebiasaan belajar yang diujikan kepada subjek penelitian, digunakan untuk mengklasifikasikan siswa atas tingkat kebiasaan belajar baik dan kebiasaan belajar yang tidak baik. Adapun desain penelitian ini dapat dilihat pada Tabel 1.

Tabel 1. Desain Faktorial 2 x 2

\begin{tabular}{|c|c|c|}
\hline \multirow{2}{*}{$\begin{array}{c}\text { Kebiasaan } \\
\text { Belajar (B) }\end{array}$} & \multicolumn{2}{|c|}{ Strategi pembelajaran (A) } \\
\cline { 2 - 3 } & $\begin{array}{c}\text { Investigasi Kelompok } \\
\text { (A1) }\end{array}$ & $\begin{array}{c}\text { Ekspositori } \\
\text { (A2) }\end{array}$ \\
\hline Baik (B1) & A1B1 & A2B1 \\
\hline Kurang Baik (B2) & A1B2 & A2B2 \\
\hline
\end{tabular}

Keterangan:

A1B1 : Hasil belajar biologi siswa yang dibelajarkan dengan strategi pembelajaran kooperatif tipe investigasi kelompok pada siswa dengan kebiasaan belajar baik.

A1B2 : Hasil belajar biologi siswa yang dibelajarkan dengan menggunakan strategi pembelajaran kooperatif tipe investigasi kelompok pada siswa dengan kebiasaan belajar yang tidak baik.

A2B1 : Hasil belajar biologi siswa yang dibelajarkan dengan menggunakan strategi pembelajaran ekspositori pada siswa dengan kebiasaan belajar baik.

A2B2 : Hasil belajar biologi siswa yang dibelajarkan dengan menggunakan strategi pembelajaran ekspositori pada siswa dengan kebiasaan belajar yang tidak baik

Teknik analisis data yang digunakan adalah teknik analisis varians (ANAVA) dua jalur. Taraf signifikan yang digunakan adalah $\alpha$ $=0,05$. Dalam menggunakan ANAVA dua jalur, dilakukan uji normalitas dengan menggunakan uji Lilifors, uji homogenitas varians dengan menggunakan uji Fisher dan uji homogenitas antar varians kelompok dengan uji Bartlett. Uji lanjut terhadap interaksi antar variabel menggunakan uji Scheffe karena jumlah subjek penelitian tiap sel berbeda.

Adapun hipothesis dalam penelitian ini adalah:

Hipotesis pertama:

Ho : $\mu A_{1} \leq \mu A_{2}$

Ha : $\mu A_{1}>\mu A_{2}$

Hipotesis kedua:

Ho : $\mu B_{1} \leq \mu B_{2}$

Ha : $\mu B_{1}>\mu B_{2}$

Hipotesis ketiga:

Ho : A X B $=0$

$\mathrm{Ha} ; \mathrm{A} X \mathrm{X} \neq 0$

\section{HASIL DAN PEMBAHASAN \\ Hasil}

Berdasarkan data hasil belajar biologi yang merupakan hasil penelitian atas siswasiswi SMP T.D. Pardede Foundation, maka diperoleh gambaran mengenai distribusi skor 
subjek penelitian. Data ini diperoleh melalui perlakuan yang berbeda, yaitu perlakuan strategi pembelajaran kooperatif tipe investigasi kelompok dan perlakuan strategi pembelajaran ekspositori, dengan variable moderator kebiasaan belajar baik dan kebiasaan belajar yang tidak baik. Skor diperoleh berdasarkan hasil test belajar yang dilaksanakan setelah perlakuan yang diberikan berakhir, dan kemudian diolah sebagai hasil belajar biologi. Kemudian berdasarkan hasil angket yang diberikan, maka siswa tersebut dibedakan menjadi 3 kelompok, yaitu kebiasaan belajar baik, kebiasaan belajar sedang, dan kebiasaan belajar tidak baik. Namun yang akan dipakai dalam uji statistik hanya 2 kelompok saja, yaitu: siswa yang memiliki kebiasaan belajar baik dan siswa yang memiliki kebiasaan belajar tidak baik, sedangkan siswa yang memiliki kebiasaan belajar kategori sedang tidak diikutsertakan dalam uji statistik.

Setelah uji normalitas dan homogenitas dilakukan, data yang didapatkan berdistribusi normal dan mempunyai varians yang homogen, kemudian dilakukan pengujian hipotesis penelitian. Pengujian hipotesis dalam penelitian ini menggunakan Analisis Varians (ANAVA) dua jalan, kemudian dilanjutkan dengan uji Scheffe yang bertujuan untuk mengetahui perbedaan diantara masing-masing kelompok yang dibandingkan. Dengan demikian, pada akhirnya akan diketahui kelompok sampel mana yang lebih unggul atau lebih tinggi dari hasil tes kelompok yang dibandingkan.

Pengujian pasangan hipotesis statistik, sesuai dengan teknik analisis data dengan ANAVA $2 \times 2$ dapat dilihat pada ringkasan Tabel

Tabel 2. Ringkasan Hasil Perhitungan Anava Dua Jalan

\begin{tabular}{|c|c|c|c|c|c|c|c|}
\hline \multirow{2}{*}{\multicolumn{2}{|c|}{$\begin{array}{ll}\text { Kebiasaan } & \text { Strategi Pembelajaran } \\
\text { Belajar } & \end{array}$}} & \multicolumn{4}{|c|}{ Strategi Pembelajaran $(\mathrm{A})$} & \multirow{2}{*}{\multicolumn{2}{|c|}{ TOTAL }} \\
\hline & & \multicolumn{2}{|c|}{$\begin{array}{l}\text { SPIK } \\
\text { (A1) }\end{array}$} & \multicolumn{2}{|c|}{$\begin{array}{l}\text { SPE } \\
\text { (A2) }\end{array}$} & & \\
\hline \multirow{6}{*}{$\begin{array}{l}\text { Kebiasaan } \\
\text { Belajar } \\
\text { Siswa } \\
\text { (B) }\end{array}$} & \multirow{3}{*}{$\begin{array}{l}\text { Baik } \\
\text { (B1) }\end{array}$} & $\mathrm{n}_{11}$ & 10 & $\mathrm{n}_{21}$ & 14 & $\mathrm{n}_{1}$ & 24 \\
\hline & & $\mathrm{T}_{11}$ & 904 & $\mathrm{~T}_{21}$ & 1129 & $\mathrm{~T}_{1}$ & 2033 \\
\hline & & $\mathrm{Xr}_{11}$ & 90,40 & $\mathrm{Xr}_{21}$ & 80,64 & $\mathrm{Xr}_{1}$ & 84,71 \\
\hline & \multirow{3}{*}{$\begin{array}{l}\text { Tidak Baik } \\
\text { (B2) }\end{array}$} & $\mathrm{n}_{12}$ & 11 & $\mathrm{n}_{22}$ & 13 & $\mathrm{n}_{2}$ & 24 \\
\hline & & $\mathrm{T}_{12}$ & 678 & $\mathrm{~T}_{22}$ & 804 & $\mathrm{~T}_{2}$ & 1482 \\
\hline & & $\mathrm{Xr}_{12}$ & 61,64 & $\mathrm{Xr}_{22}$ & 61,85 & $\mathrm{Xr}_{2}$ & 61,75 \\
\hline \multirow{3}{*}{\multicolumn{2}{|c|}{ TOTAL }} & $\mathrm{n}_{1}$ & 21 & $\mathrm{n}_{2}$ & 27 & $\mathrm{Nt}$ & 48 \\
\hline & & $\mathrm{T}_{2}$ & 1582 & $\mathrm{~T}_{2}$ & 1933 & $\mathrm{Tt}$ & 3515 \\
\hline & & $\mathrm{Xr}_{1}$ & 75,33 & $\mathrm{Xr}_{2}$ & 71,59 & $\mathrm{Xrt}$ & 73,46 \\
\hline
\end{tabular}

Secara keseluruhan rangkuman hasil perhitungan ANAVA dengan factorial 2 x 2 untuk pengujian hipotesis penelitian dapat dilihat pada tabel 4.15.

Tabel 3. Ringkasan Pengujian Hipotesis Pengaruh Strategi Pembelajaran dan Kebiasaan Belajar Terhadap Hasil Belajar Biologi.

\begin{tabular}{|c|c|c|c|c|c|}
\hline Sumber Varians & JK & Dk & KT & F Hitung & F Tabel ( 0,05) \\
\cline { 1 - 4 } Baris & 6325,02 & 1 & 6325,02 & 179,13 & \multirow{2}{*}{4,06} \\
\cline { 1 - 4 } Kolom & 165,29 & 1 & 165,29 & 4,68 & \\
\hline Dalam & 1553,85 & 44 & 35,31 & - & \\
\cline { 1 - 4 } Interaksi & 390,32 & 1 & 390,32 & 11,05 & \\
\hline
\end{tabular}

Data yang diperoleh dalam penelitian ini berasal dari sampel yang jumlahnya tidak sama dalam sel ANAVA, sehingga perlu diadakan Uji Scheffe. Ringkasan hasil perhitungan uji lanjut dapat dilihat pada Tabel 4. 
Tabel 4. Ringkasan Hasil Perhitungan Uji Lanjut ( Uji Scheffe).

\begin{tabular}{|c|c|c|c|c|}
\hline No. & $\begin{array}{c}\text { Skor Kelompok Yang } \\
\text { Dibandingkan }\end{array}$ & F hitung & $F$ table $(3 ; 44)$ & \\
& $\mathrm{A}_{1} \mathrm{~B}_{1}$ dengan $\mathrm{A}_{1} \mathrm{~B}_{2}$ & 11,08 & $\alpha=5 \%$ & Keterangan \\
\hline 1 & $\mathrm{~A}_{1} \mathrm{~B}_{1}$ dengan $\mathrm{A}_{2} \mathrm{~B}_{1}$ & 3,97 & 2,82 & Signifikan \\
\hline 2 & $\mathrm{~A}_{1} \mathrm{~B}_{1}$ dengan $\mathrm{A}_{2} \mathrm{~B}_{2}$ & 11,42 & 2,82 & Signifikan \\
\hline 3 & $\mathrm{~A}_{2} \mathrm{~B}_{1}$ dengan $\mathrm{A}_{2} \mathrm{~B}_{2}$ & 8,21 & 2,82 & Signifikan \\
\hline 4 & $\mathrm{~A}_{1} \mathrm{~B}_{2}$ dengan $\mathrm{A}_{2} \mathrm{~B}_{2}$ & 0,09 & 2,82 & Signifikan \\
\hline 5 & $\mathrm{~A}_{2} \mathrm{~B}_{1}$ dengan $\mathrm{A}_{1} \mathrm{~B}_{2}$ & 7,94 & 2,82 & Tidak Signifikan \\
\hline 6 & \multicolumn{2}{|l}{} \\
\hline
\end{tabular}

Berdasarkan hasil pengujian hipotesis di atas, dapat dilihat bahwa ada interaksi antara perlakuan strategi pembelajaran dengan kebiasaan belajar siswa. Bentuk interaksi tersebut dapat dilihat pada gambar 1.

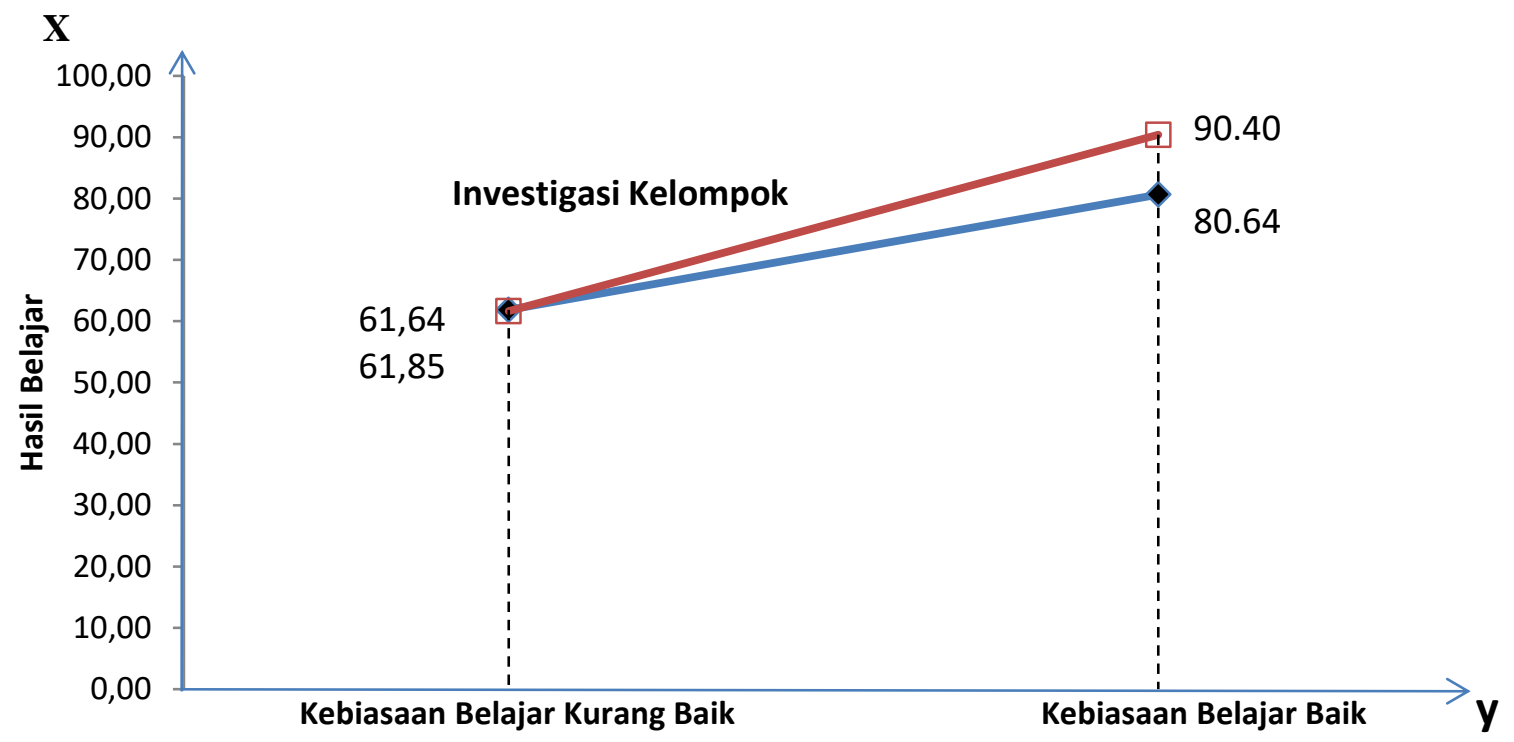

Gambar 1: Diagram interaksi antara perlakuan strategi pembelajaran dan kebiasaan belajar siswa.

\section{Pembahasan}

Hasil penelitian menunjukkan bahwa secara keseluruhan kelompok siswa yang mendapat perlakuan strategi pembelajaran investigasi kelompok memiliki nilai yang lebih tinggi daripada kelompok siswa yang mendapat perlakuan strategi pembelajaran ekspositori. Hal ini kemungkinan disebabkan karena dengan menerapkan strategi pembelajaran investigasi kelompok, siswa akan saling bekerjasama dalam memecahkan masalah. Mereka belajar untuk bersosialisasi dengan baik, saling mengajari, saling menghargai, dan meningkatkan semangat kekeluargaan, sehingga masing-masing individu bisa meningkatkan keterlibatan dalam kelompok. Dengan adanya saling bekerja sama, membuat mereka tidak mudah menyerah, dan suasana yang akrab dalam kerjasama tersebut membuat mereka merasa nyaman dalam belajar. Mereka akan saling berdiskusi dan berbagi tugas dalam menyelesaikan suatu topik masalah yang ditetapkan untuk diselesaikan. Masing-masing siswa akan menyumbangkan pendapat dan ide masing-masing demi kemajuan bersama, mereka bersama-sama mencari ilmu tersebut seperti layaknya seorang ilmuwan. Situasi inilah yang membuat mereka dapat lebih memahami materi yang sedang mereka selidiki, sehingga inilah yang menyebabkan hasil belajar kelompok siswa yang mendapat perlakuan strategi pembelajaran investigasi kelompok lebih unggul dibandingkan dengan kelompok siswa yang mendapat perlakuan strategi pembelajaran ekspositori.

Pada strategi pembelajaran ekspositori, proses penyampaian materi terpusat pada guru dengan gaya komunikasi satu arah. Hal ini menyebabkan pengetahuan yang dimiliki siswa akan terbatas pada apa yang diberikan oleh guru. Ini membuat kemampuan berpikir kritis menjadi kurang berkembang. Siswa akan 
cenderung belajar fakta dan konsep, tetapi kurang memiliki keterampilan sikap dan keterampilan ilmiah. Inilah kemungkinan penyebab prestasi belajar biologi siswa yang mendapat perlakuan strategi pembelajaran ekspositori lebih rendah dibandingkan dengan kelompok siswa yang mendapat perlakuan strategi pembelajaran investigasi kelompok.

Temuan penelitian ini sejalan dengan yang dinyatakan oleh Joyce et. al. (2009) bahwa ciri menarik lain dari strategi pengelompokan ini adalah posisinya yang "memihak" pada siswa dengan prestasi akademik rendah. Golongan ini bisa memanfaatkan strategi pengelompokan secara langsung. Pengelompokan meningkatkan rasa keterlibatan. Fokus untuk bekerjasama juga merupakan suatu hal yang dapat menghilangkan sifat yang cepat menyerah dan meningkatkan tanggung jawab belajar pribadi. Dengan konsisten dan bertahap, sistem ini akan membuat semua siswa, dalam hal ini anggota kelompok, untuk memiliki sifat yang rendah hati. Kapasitas efek dari pembelajaran sosial dan penghargaan terhadap diri siswa bisa terlihat jelas jika dibandingkan dengan organisasi ruang kelas yang tidak menerapkan sistem pengelompokan.

Dalam Sanjaya (2009) juga dinyatakan bahwa beberapa kelemahan dari strategi pembelajaran ekspositori adalah: strategi ini sangat tergantung pada apa yang dimiliki oleh guru seperti persiapan, pengetahuan, rasa percaya diri, semangat, antusiasme, motivasi dan berbagai kemampuan untuk keberhasilan proses pembelajaran; strategi ini tidak mungkin dapat melayani perbedaan setiap individu; pada strategi ini lebih banyak diberikan melalui ceramah sehingga sulit mengembangkan kemampuan siswa dalam hal kemampuan sosialisasi, hubungan interpersonal serta kemampuan berpikir kritis.

Setiap orang pasti pernah belajar, baik belajar akademis maupun belajar dalam kehidupan sehari-hari. Belajar merupakan petualangan seumur hidup, perjalanan eksplorasi tanpa akhir untuk menciptakan pemahaman personal kita sendiri. Petualangan itu haruslah melibatkan kemampuan untuk secara terus menerus menganalisis dan meningkatkan cara seseorang belajar. Setiap siswa di sekolah pasti memiliki kebiasaan yang berbeda-beda dalam menerapkan cara-cara belajar. Ada yang memiliki kebiasaan belajar baik, sedang dan kebiasaan belajar yang tidak baik. Siswa yang memiliki kebiasaan belajar baik, mereka akan melakukan aktivitas belajar secara terencana dan teratur. Kebiasaan belajar tersebut meliputi kebiasaan yang dilakukan dalam rutinitas belajar yang terjadwal, mencatat, membaca, menghafal, eksplorasi logis matematis dan memberi pendapat dalam kelompok atau kelas. Dengan menerapkan aktivitas belajar tersebut secara teratur, maka siswa akan mampu menguasai materi pelajaran khususnya materi pelajaran biologi di sekolah dengan baik, mereka akan mampu mengatasi masalah yang ada dalam pembelajaran biologi dengan rajin membaca buku, melakukan eksplorasi logis matematis, memiliki rasa percaya diri yang baik tentang apa yang telah mereka ketahui, dan memiliki disiplin yang baik dalam penggunaan waktu.

Hasil belajar kelompok siswa yang memiliki kebiasaan belajar yang baik lebih tinggi daripada kelompok siswa yang memiliki kebiasaan belajar yang tidak baik disebabkan karena siswa yang memiliki kebiasaan belajar yang baik mereka akan secara rutin menerapkan cara-cara belajar dalam aktivitas belajar mereka. Penerapan secara rutin tersebut akan memudahkan mereka untuk mengingat kembali (retrievel) informasi tentang materi pelajaran yang telah tersimpan sebelumnya pada ingatan mereka yang terdapat pada otak.

Selain itu, kebiasaan belajar yang baik mempengaruhi perkembangan emosi, motivasi, perilaku serta kepribadian mereka. Mereka akan memiliki motivasi yang kuat untuk tetap mau belajar sebab mereka mengetahui betapa banyak manfaat yang akan mereka miliki melalui belajar, mereka menganggap bahwa belajar itu bukan lagi suatu beban yang harus dihindari, melainkan sesuatu hal yang menyenangkan yang akan mereka lakukan dengan kesadaran sendiri.

Sedangkan siswa yang memiliki kebiasaan belajar yang tidak baik, mereka menerapkan cara-cara belajar secara tidak rutin dalam aktivitas belajar mereka. Sehingga mereka memiliki daya ingat yang kurang baik. Kebiasaan belajar yang tidak baik inipun mempengaruhi perkembangan emosi, motivasi, kepribadian dan perilaku mereka. Mereka akan cenderung menganggap belajar sebagai suatu beban dan kurang termotivasi untuk belajar. Seperti yang dinyatakan oleh Atkinson et.al., (1983) belajar merupakan dasar untuk memahami perilaku. Belajar berkaitan juga dengan masalah fundamental tentang perkembangan emosi, motivasi, perilaku sosial dan kepribadian. Segala macam belajar 
melibatkan ingatan (memory). Seperti yang kita ketahui, bahwa ingatan terdapat pada otak. Menurut Dryde \& Jeannette Vos (2003) otak akan mampu bekerja secara efektif dengan menggunakannya secara teratur, sehingga proses belajarpun akan menjadi lebih mudah dan lebih sederhana. Sehingga penerapan secara teratur terhadap aktivitas belajar akan mengefektifkan otak bekerja yang dapat meningkatkan hasil belajar.

Kelompok siswa yang mendapat perlakuan strategi pembelajaran investigasi kelompok memiliki hasil belajar yang lebih baik bila dibandingkan dengan penerapan strategi pembelajaran ekspositori untuk materi pelajaran biologi pada IPA terpadu dengan topik ciri-ciri makhluk hidup. Ini menunjukkan strategi ini sangat tepat sesuai dengan materi pelajaran yang diajarkan. Strategi yang tepat dapat meningkatkan hasil belajar siswa. Strategi yang tepat dengan kebiasaan belajar yang baik akan memaksimalkan kemampuan siswa dalam menguasai materi pelajaran. Dalam strategi pembelajaran investigasi kelompok, mereka berperan aktif bekerjasama untuk mencapai tujuan kelompok. Maka terjadilah pembelajaran yang bersifat sosial, yang dapat melibatkan lebih banyak daya otak keseluruhan dan meningkatkan kualitas dan kuantitas belajar. Selain kerjasama dalam kelompok, kebiasaan belajar yang baik membuat mereka lebih termotivasi dalam belajar. Kebiasaan belajar yang baik dan kerjasama dalam kelompok saat belajar dapat memaksimalkan kerja otak dalam belajar, hal ini akan memperkuat ingatan sipelajar tentang materi pelajaran yang sedang dipelajari, dan berpengaruh terhadap hasil belajar siswa tersebut.

Hasil belajar yang lebih baik terdapat pada kelompok siswa yang memiliki kebiasaan belajar baik yang mendapat perlakuan strategi pembelajaran investigasi kelompok. Hal ini disebabkan karena dalam proses pembelajaran, strategi pembelajaran investigasi kelompok melibatkan peran aktif dari setiap anggota kelompok. Setiap anggota kelompok bekerjasama untuk mencapai tujuan kelompok. Mereka saling memberi ide, saling berbagi informasi dan saling menolong dalam melakukan penyelidikan tentang materi yang mereka kerjakan. Maka terjadilah pembelajaran yang bersifat sosial, yang dapat melibatkan lebih banyak daya otak keseluruhan dan meningkatkan kualitas dan kuantitas belajar. Selain kerjasama dalam kelompok, kebiasaan belajar yang baik membuat mereka lebih termotivasi dalam belajar. Mereka menganggap aktivitas belajar merupakan aktivitas yang menyenangkan. Kebiasaan belajar yang baik dan kerjasama dalam kelompok saat belajar dapat memaksimalkan kerja otak dalam belajar, hal ini akan memperkuat ingatan sipelajar tentang materi pelajaran yang sedang dipelajari, dan berpengaruh terhadap hasil belajar siswa tersebut.

Sedangkan siswa yang memiliki kebiasaan belajar yang baik tetapi mendapat perlakuan strategi pembelajaran ekspositori, dalam proses pembelajaran lebih banyak diberikan melalui ceramah, gaya komunikasi lebih banyak terjadi satu arah antara guru dan siswa. Antara satu siswa dengan siswa lainnya kurang bekerjasama dalam belajar, cenderung bersifat individualis dan saling bersaing yang dapat memperlambat pembelajaran. Meskipun siswa tersebut memiliki kebiasaan belajar yang baik, tetapi karena kurangnya kerjasama dengan siswa yang lain, maka daya otak dalam belajar kurang maksimal, sehingga mempengaruhi kualitas dan hasil belajar.

Demikian pula siswa yang memiliki kebiasaan belajar yang tidak baik dan mendapat perlakuan strategi pembelajaran ekspositori, strategi ini membantu siswa dalam memahami pelajaran yang diberikan oleh gurunya, tetapi kebiasaan belajar yang tidak baik menyebabkan siswa tersebut tidak mampu menguasai materi pelajaran secara maksimal.

Seperti yang dinyatakan oleh Rakhmat (2002) bahwa dalam kelompok, setiap anggota kelampok akan saling berbagi informasi dan saling bekerjasama dalam mencapai tujuan kelompok yang menyebabkan mereka saling bersosialisasi dengan baik.

Juga dalam Meier (2003) menyatakan bahwa kerjasama membantu proses belajar. Semua usaha belajar yang baik mempunyai landasan sosial. Kita biasanya belajar lebih banyak dengan berinteraksi dengan kawankawan daripada dengan yang kita pelajari dengan cara lain manapun. Persaingan diantara pelajar memperlambat pembelajaran. Tetapi kerjasama diantara mereka dapat mempercepat pembelajaran. Suatu komunikasi dalam belajar akan lebih baik hasilnya daripada beberapa individu yang belajar sendiri-sendiri. Pembelajaran yang bersifat sosial dapat menyebabkan adanya kerjasama diantara para pelajar. Kerjasama diantara para pelajar dapat melibatkan lebih banyak daya otak keseluruhan dan meningkatkan kualitas dan kuantitas belajar. 
Siswa yang memiliki kebiasaan belajar yang tidak baik yang mendapat strategi pembelajaran ekspositori akan memiliki daya ingat yang lebih lemah, karena tidak sering mengulang materi pelajarannya dirumah, selain itu, siswa tersebut akan tergantung pada apa yang disampaikan oleh gurunya, kurang kerjasama dengan teman-temannya untuk berbagi pengetahuan.

Sedangkan kelompok siswa yang memiliki kebiasaan belajar yang baik yang mendapat strategi pembelajaran investigasi kelompok, mereka tidak hanya tergantung pada apa yang disampaikan oleh gurunya, tetapi juga mendapat pengetahuan dari hasil kerjasama dengan teman-temannya. Kebiasaan belajar yang baik turut memaksimalkan hasil belajar mereka, sehingga mereka memiliki hasil belajar yang lebih baik.

Meskipun kedua kelompok tersebut sama-sama mendapat perlakuan strategi pembelajaran ekspositori, namun kelompok siswa yang memiliki kebiasaan belajar yang baik akan memiliki daya ingat yang lebih baik sebab mereka sering mengulang pelajaran mereka di rumah daripada kelompok siswa yang memiliki kebiasaan belajar yang tidak baik. Sehingga hasil belajar kelompok siswa yang memiliki kebiasaan belajar yang baik akan lebih tinggi daripada kelompok siswa yang memiliki kebiasaan belajar yang tidak baik dengan perlakuan yang sama yaitu strategi pembelajaran ekspositori.

\section{PENUTUP}

\section{Simpulan}

Berdasarkan hasil penelitian dan pembahasan yang telah dikemukakan sebelumnya, dapat ditarik simpulan sebagai berikut:

1. Pemberian Strategi pembelajaran mempengaruhi hasil belajar biologi, dimana kelompok siswa yang diberi perlakuan dengan strategi pembelajaran kooperatif tipe investigasi kelompok lebih tinggi daripada hasil belajar biologi siswa yang diajar dengan menerapkan strategi pembelajaran ekspositori.

2. Hasil belajar biologi siswa yang memiliki kebiasaan belajar baik lebih tinggi daripada hasil belajar biologi siswa yang memiliki kebiasaan belajar yang tidak baik secara keseluruhan. Ini berarti siswa yang memiliki kebiasaan belajar yang baik lebih baik dalam penguasaan materi pelajaran daripada siswa yang memiliki kebiasaan belajar yang tidak baik.

3. Terdapat interaksi antara strategi pembelajaran dan kebiasaan belajar siswa terhadap hasil belajar biologi siswa. Semakin baik kebiasaan belajar seorang siswa, maka penerapan strategi pembelajaran akan menunjukkan hasil yang semakin memuaskan. Jika siswa mendapat pengajaran dengan strategi pembelajaran investigasi kelompok dengan kebiasaan belajar yang baik maka hasilnya akan jauh lebih baik bila dibandingkan dengan siswa yang memiliki kebiasaan belajar yang baik dan mendapat pengajaran dengan strategi pembelajaran ekspositori, karena siswa yang memiliki kebiasaan belajar yang baik dan mendapat pengajaran dengan strategi investigasi kelompok akan lebih memahami dan menguasai materi pelajarannya, sebab saat melakukan investigasi kelompok, siswa akan saling bekerjasama dengan temannya yang dapat melibatkan daya otak secara keseluruhan, dan kebiasaannya yang baik dalam belajar akan memperkuat ingatan dan kemampuan analisanya sehingga memaksimalkan kerja otak yang dapat meningkatkan kuantitas dan kualitas belajar. Semakin rendah kebiasaan belajar siswa, maka hasil belajarnyapun akan tetap rendah meskipun mendapat strategi pembelajaran ekspositori ataupun strategi pembelajaran investigasi kelompok. Tetapi untuk siswa yang memiliki kebiasaan belajar rendah lebih baik mendapatkan strategi pembelajaran ekspositori daripada investigasi kelompok, sebab strategi ekspositori ini dapat meningkatkan hasil belajar siswa yang memiliki kebiasaan belajar rendah daripada strategi investigasi kelompok meskipun secara statistik tidak signifikan.

\section{Saran}

Berdasarkan kesimpulan dan implikasi penelitian yang dipaparkan di atas, maka disampaikan saran-saran sebagai berikut:

1. Untuk meningkatkan hasil belajar biologi, sebaiknya guru mata pelajaran biologi di SMP menerapkan strategi pembelajaran investigasi kelompok namun disesuaikan dengan topik pelajaran yang disampaikan.

2. Secara umum, perlakuan strategi pembelajaran investigasi kelompok bagi siswa yang memiliki kebiasaan belajar yang baik hasilnya lebih baik dalam 
meningkatkan hasil belajar biologi, disarankan agar menggunakan strategi pembelajaran investigasi kelompok terhadap siswa yang memiliki kebiasaan belajar yang baik.

3. Guru sebaiknya memperhatikan kebiasaan belajar siswa, kemudian selalu memberi motivasi dan memberi tips-tips belajar yang mudah dimengerti oleh siswa agar siswa termotivasi untuk memiliki kebiasaan belajar yang baik.

4. Pihak sekolah dan orang tua diharapakan saling bekerjasama dalam memantau kebiasaan belajar siswa yang berpengaruh terhadap hasil belajar siswa.

5. Dalam penelitian ini, peneliti memiliki keterbatasan untuk mengamati secara langsung bagaimana kebiasaan belajar siswa di rumah. Bagi peneliti selanjutnya yang tertarik untuk meneliti tentang kebiasaan belajar, untuk mendapatkan hasil yang lebih akurat lagi, selain menggunakan angket disarankan untuk melakukan pengamatan secara langsung dan tersembunyi terhadap kebiasaan aktivitas belajar siswa baik di rumah maupun di sekolah.

\section{DAFTAR PUSTAKA}

Aiken, L.R., Groth, G., Marnat. 2009. Pengetesan dan Pemeriksaan Psikologi. jilid 2. ed. 12. Jakarta: Indeks.

Arikunto, S. 2007. Manajemen Penelitian. cet. 9. Jakarta: Rineka Cipta.

De Porter, B. \& Hernacki, M. 2002. Quantum Learning: Membiasakan Belajar Nyaman dan Menyenangkan. Alih Bahasa: Alwiya Abdurrahman. bandung: Kaifa.

Djamarah, S.B. \& Zain, A. 2006. Strategi Belajar Mengajar. cet. 3. Jakarta: Rineka Cipta.

Dryde, G., Jeannette Vos. 2003. Revolusi Cara Belajar (The Learning Revolution). Belajar akan efektif kalau anda dalam keadaan "fun", Bagian 1: Keajaiban Pikiran. Bandung: Kaifa.

Hamid, A. 2009. Teori Belajar dan Pembelajaran. ed. 2. cet. 2. Medan: Unimed Press.

Meier, D. 2003. The Accelerated Learning, Hand book, Panduan Kreatif dan Efektif Merancang Program Pendidikan dan Pelatihan. cet. 3. Bandung: Kaifa.

Joyce, B. \& Weil, M. 1996. Models of Teaching. Inc, publishing as Allyn \& Bacon. New Jersey, USA: Needham Heights. Mass.
Joyce, B. Weil, M., Calhoun, E. 2009. Models of Teaching (Model-Model Pengajaran). cet. 1. ed. 8. Yogyakarta: Pustaka Pelajar.

Klein, S.B. 1996. Learning: Principles and Application. New York: M.C. Graw-Hill. Book Co.

Mudjiono \& Dimyati. 2006. Belajar dan Pembelajaran. cet. 3. Jakarta: Rineka Cipta.

Nicholl, M.J. \& Rose, C. 2002. Accelerated Learning For The $21^{\text {st }}$ Century. Cara Belajar Cepat Abad XXI. cet. 3. Bandung: Nuansa.

Rakhmat, J. 2002. Psikologi Komunikasi. edisi revisi. cet. 18 . Bandung: Remaja Rosdakarya.

Reece, C. \& Mitchell. 2004. Biologi. ed.5. jilid 3. Jakarta: Erlangga.

Saktiyono. 2007. IPA Biologi 1 SMP dan MTs untuk kelas VII. Jakarta: Esis.

Sanjaya, W. 2009. Strategi Pembelajaran Berorientasi Standar Proses Pendidikan. Ed. 1. cet. 6. Jakarta: Kencana.

Slavin, R.E. 1995. Cooperative Learning, Theory, Research, and Practice, second edition. New jersey USA: Inc, publishing as Allyn \& Bacon.

Sudjana. 2002. Metoda Statistika. ed. 6. Bandung: Tarsito.

Sunardi \& Nurhayati, N. 2007. Panduan Ujian Nasional IPA (IPA-Fisika, IPA-Biologi, IPA-Kimia). Untuk Kelas 3 SMP/MTs. Tim Kreatif Quantum. cet. 1. Bandung: Yrama Widya.

Sumarwan, Sumartini \& Kusmayadi. 2004. Sains Biologi 1A untuk SMP Kelas VII. Semester 1. Jakarta: Erlangga.

Surapranata, S. 2005. Analisis Validitas, Reabilitas dan Interpretasi Hasil Test. Implementasi Kurikulum 2004. cet. 2. Bandung: Remaja Rosdakarya.

Syah, M. 2010. Psikologi Belajar. ed. revisi-10. Jakarta: Rajawali Pers.

Syamsuri, I. 2007. Biologi 1A. untuk kelas SMA Kelas $X$ semester 1. cet. 10. Jakarta: Erlangga.

Trianto. 2009. Mendesain Strategi pembelajaran Inovatif Progresif. ed. 1. cet. 1. Jakarta: Kencana. 